\title{
Energy balance of biodiesel production from canola
}

\author{
Luis Felipe Lima e Silva ${ }^{1}$ Wilson Magela Gonçalves ${ }^{2}$ Wilson Roberto Maluf $^{2}$ \\ Luciane Vilela Resende ${ }^{2}$ Christiany Mattioli Sarmiento ${ }^{3}$ Vicente Licursi $^{2}$ Paulo Moretto ${ }^{2}$
}

1Programa de Pós-doutorado em Fitotecnia, Departamento de Agricultura, Universidade Federal de Lavras (UFLA), 37200-000, Lavras, MG,
Brasil. Email: luisufla@hormail.com. "Corresponding author.
${ }^{2}$ Departamento de Agricultura, Universidade Federal de Lavras (UFLA), Lavras, MG, Brasil.
${ }^{3}$ Programa de Doutorado em Engenharia Agrícola, Departamento de Engenharia, Universidade Federal de Lavras (UFLA), Lavras, MG, Brasil.

ABSTRACT: The aim of the present study was to estimate the energy balance (output/input ratio) of the canola crop for biodiesel production, under Brazilian conditions. Fossil energy expended in the production of 600kg of oil per hectare was 7,146,537kcal. The estimated energy yield per hectare was $9,930,000 \mathrm{kcal}$ from the production of $1,500 \mathrm{~kg} \mathrm{ha}^{-1}$ of seeds $(40 \%$ oil and $60 \%$ oil cake), which resulted in an energy balance of 1.39. Results indicated the viability of biofuel production from canola, but also showed the need to improve the technology used to increase the energy and economic balance ratios.

Key words: Brassica napus L. var. oleifera, biofuel, energy sustainability.

Balanço energético da cultura de canola visando à produção de biodiesel

RESUMO: $O$ objetivo do trabalho foi estimar o balanço energético (razão output/input) da cultura da canola, nas condições brasileiras, para a produção de biodiesel. A energia fóssil dispendida na produção de $600 \mathrm{~kg}$ de óleo por hectare foi de $7.146 .537 \mathrm{kcal}$. O rendimento energético estimado por hectare foi de $9.930 .000 \mathrm{kcal}$, a partir da produtividade de $1.500 \mathrm{~kg}$ hal de grãos (40\% de óleo e $60 \%$ de torta), resultando no valor do balanço energético de 1,39. Os resultados indicam a viabilidade da produção do biocombustível com base na respectiva cultura, mas demonstram também a necessidade de aperfeiçoamento das tecnologias empregadas para que se aumentem os índices dos balanços energético e econômico. Palavras-chave: Brassica napus L. var. oleifera, biocombustível, sustentabilidade energética.

\section{INTRODUCTION}

The main global energy matrix is composed of non-renewable fossil carbon sources such as petroleum $(35 \%)$, coal (23\%), and natural gas $(21 \%)$, and it is highly likely that these sources will become scarce in the coming decades. Moreover, the extensive use of these fuels is potentially damaging to the environment (SOUZA, 2008). The global production of biodiesel has significantly increased in recent years, and there is a growing interest in gradually replacing fossil fuels with biofuels (GARCEZ \& VIANNA, 2009).

Brazil has great potential for the production of biofuels, since it has a rich diversity of agricultural species that can potentially be used for this purpose, and because a labor force and land are readily available. Due to these characteristics, Brazil is in a good position to be a powerhouse in the international market of the renewable fuel production agribusiness. Despite the optimism involved, the amount of energy invested in a production system has often been greater than the return obtained in the form of the energy value of products, which leads to a negative balance and thereby compromises the sustainability of the system (PIMENTEL \& PATZEK, 2005). Therefore, several studies have been conducted with the aim of assessing the efficiency of new renewable energy, in order to determine the economic and energetic viability of biofuel production. Energy balance, 
defined by CAMPOS \& CAMPOS (2004) as the ratio between the energy produced per unit of area (production/ha) and the energy consumed per unit of area (input/ha), has been used as an instrument in these studies.

Although the main crop used to obtain biodiesel in Brazil is soybean (KOHLHEPP, 2010), other crops such as canola are potentially suited for this purpose in the central, southeast, and southern regions of Brazil. Rapeseed/canola (Brassica napus L. var. oleifera) is an important feedstock for biodiesel production due to the high oil content in the grains ( $40 \%$ to $46 \%$ ). In Brazil, canola is an excellent crop option, for both production of oils for human consumption and agroenergy purposes, and is mainly exported to Europe and other countries where conditions in winter are severe (TOMM et al., 2009). Although there are good prospects for the use of canola in biodiesel production in Brazil, studies that indicate the viability of canola for this purpose are scarce in the country.

The aim of the present study was to estimate the energy balance of the rapeseed/canola crop for biodiesel production under Brazilian conditions within its chain production. This estimate was derived from the relationship between the energy requirements and input costs for fuel production (inputs) and the energy associated with the yields of its combustion added to the energy potential of the oil cake obtained as an industrial by-product (outputs), which are important indicators of the energy viability of biodiesel production.

\section{MATERIALS AND METHODS}

To calculate the energy balance of the canola (Brassica napus L. var. oleifera) crop, the different activities involved in the production system were divided into an agricultural and an industrial phase.

The agricultural phase was conducted via a field experiment in which the invested mechanized and manual operations were estimated, as well as all the inputs used, according to the technical recommendations for the crop's management (BATCHELOR et al., 1995; PIMENTEL \& PATZEK, 2005; TOMM, 2006; TOMM et al., 2009; LIMA, 2009; GARAVAND et al., 2010). The experiment was conducted in a rural property in the municipality of Itumirim-MG (latitude $21^{\circ} 16^{\prime} 35^{\prime \prime} \mathrm{S}$, longitude $44^{\circ} 49^{\prime} 34^{\prime \prime} \mathrm{W}$ ) between 2009 and 2010. The experimental design was in randomized blocks, with five plots of 0.2 ha each and five replicates, where the set of plants from the central part of each plot was considered as one treatment, and where a production test of the crop was conducted under local conditions and using local technologies. A mean of $4 \mathrm{~kg}$ of canola seeds were sown per hectare. Crop fertilization was performed by applying $200 \mathrm{~kg}$ of N-P-K (4-30-16) formulation, $100 \mathrm{~kg}$ of ammonium sulfate, and $71 \mathrm{~kg}$ of urea (TOMM, 2006; TOMM et al., 2009). All the remaining inputs, technologies and work force that were used are described in tables 1 and 2. Mean productivities per area were obtained, from which mean grain yields per hectare of crop were subsequently inferred.

The industrial phase included the operations of oil extraction, refining, and transesterification to obtain biodiesel, and the estimated yields were obtained in the form of oil and of oil cake, to which the total costs of the energy invested in the production process were then related. For oil extraction, grain samples were subjected to cold pressing in an expeller press. Refining and transesterification operations were performed subsequently, according to the method of BATCHELOR et al. (1995).

To estimate the energy balance, all the inputs invested in the process of grain and oil production were considered: mechanized operations, labor force, inputs, and the industrial phase (Table 1). The outputs were relative to the amount of energy in the final products. Energy efficiency was calculated using the ratio between the produced energy (outputs) and the consumed energy (inputs).

Expenditures in the mechanized operations were estimated considering direct energy (fuels, oils, and greases) and indirect energy (tractors and implements) invested in the production process of this crop. Energy inputs and outputs were subsequently related to their corresponding energy balance (Table 1), and the total energy consumed in each process and the total energy yield from the produced oil and oil cake were thus obtained. After calculating the total energy consumed and produced, the energy balance for the canola crop was estimated.

To complement the data on the potential of canola crops in the region, the production costs during the agricultural phase and the grain yields per hectare were estimated, according to the corresponding monetary relative to the market price in the region of Lavras-MG for the year 2012 (Table 2).

\section{RESULTS AND DISCUSSION}

The total fossil energy invested in the production of $600 \mathrm{~kg}$ of canola oil per hectare was estimated at $7,146,537 \mathrm{kcal}$. This yield in oil was obtained from the data in table 1 , considering that the mean grain yield for the canola crop was $1,500 \mathrm{~kg} \mathrm{ha}^{-1}$ (40\% oil and $60 \%$ oil cake). 
The estimated energy balance for biodiesel production from canola was 1.39 . This means that for each $1 \mathrm{kcal}$ of energy invested in the production system, $1.39 \mathrm{kcal}$ of energy was produced from the crop. This energy yield was estimated from the total energy produced by the crop, specifically $9,930,000 \mathrm{kcal} \mathrm{ha}^{-1}$ (Table 1), considering the values of energy contained in the produced oil and oil cake.

The agricultural phase represented approximately $63 \%$ of all the invested energy for biodiesel production, with the inputs corresponding to the major part of invested energy (approximately $25 \%$ ). Nitrogen alone represented $13.65 \%$ of the consumed energy (Table 1). The remaining energy invested in the agricultural phase resulted from the labor force, diesel fuel and mechanized operations, accounting for $22.97,7.50$, and $7.23 \%$ of all the energy invested in the production process, respectively. The industrial phase represented approximately $37 \%$ of the total energy invested in the process of oil production from canola and included the extraction, transesterification, and refining operations.

The positive energy balance obtained indicates the viability of biodiesel production from canola under the given production conditions. However, the viability of biofuel production becomes debatable when the energy balance ratios obtained in the present study; although, they represent significant yields - are compared with the energy balance ratios obtained in other studies with this crop and with other

Table 1 - Energy balance for biodiesel production from canola in the region of Itumirim, Minas Gerais, Brazil.

\begin{tabular}{|c|c|c|c|c|}
\hline Agricultural phase & Consumed & kcal & Total kcal & $\%$ \\
\hline Plowing ${ }^{1}$ & 1ha & $40959 \mathrm{ha}^{-1}$ & 40959 & 0.57 \\
\hline Harrowing ${ }^{1}$ & 1ha & $9088.09 \mathrm{ha}^{-1}$ & 9088.09 & 0.13 \\
\hline Insect spraying $^{2}$ & $0.6 \mathrm{~h} \mathrm{~m}^{-1}$ & $191076.72 \mathrm{~h}^{-1}$ & 114646 & 1.60 \\
\hline Herbic spraying $^{2}$ & $0.6 \mathrm{~h} \mathrm{~m}^{-1}$ & $191076.72 \mathrm{hm}^{-1}$ & 114646 & 1.60 \\
\hline Application of feart ${ }^{2}$ & $0.12 \mathrm{~h} \mathrm{~m}^{-1}$ & $226906.61 \mathrm{hm}^{-1}$ & 27228.79 & 0.38 \\
\hline Sowing ${ }^{1}$ & 1ha & $22217 \mathrm{ha}^{-1}$ & 22217 & 0.31 \\
\hline Harvest $^{3}$ & $1 \mathrm{~h} \mathrm{~m}^{-1}$ & $187131 \mathrm{~h} \mathrm{~m}^{-1}$ & 187131 & 2.62 \\
\hline Transportation ${ }^{4}$ & $0.5 \mathrm{~h} \mathrm{~m}^{-1}$ & $1321.4 \mathrm{~h} \mathrm{~m}^{-1}$ & 661 & 0.01 \\
\hline Total & - & - & 516577.09 & 7.23 \\
\hline \multicolumn{5}{|c|}{ } \\
\hline Total & $144 \mathrm{~L}$ & $11400 \mathrm{~L}^{-1}$ & 1641600 & 22.97 \\
\hline \multicolumn{5}{|c|}{ } \\
\hline Nitrogen ${ }^{5}$ & $60.95 \mathrm{~kg}$ & $16000 \mathrm{~kg}^{-1}$ & 975200 & 13.65 \\
\hline Phosphorous & $60 \mathrm{~kg}$ & $4154 \mathrm{~kg}^{-1}$ & 249240 & 3.49 \\
\hline Potassium & $32 \mathrm{~kg}$ & $3260 \mathrm{~kg}^{-1}$ & 104320 & 1.46 \\
\hline Glyphosate herbic ${ }^{5}$ & $1 \mathrm{~kg}$ & $100000 \mathrm{~kg}^{-1}$ & 100000 & 1.40 \\
\hline Insecticide $^{5}$ Methaminadophos ${ }^{5}$ & $2.95 \mathrm{~kg}$ & $100000 \mathrm{~kg}^{-1}$ & 295000 & 4.13 \\
\hline Seeds $^{6}$ & $4 \mathrm{~kg}$ & $21700 \mathrm{~kg}^{-1}$ & 86800 & 1.21 \\
\hline Total & - & - & 1810560 & 25.33 \\
\hline \multicolumn{5}{|c|}{ 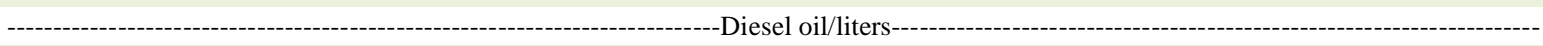 } \\
\hline Total & 47 & $11400 \mathrm{~L}^{-1}$ & 535800 & 7.50 \\
\hline Total Agrícola Phase & - & - & 4504537 & 63,03 \\
\hline Industrial Phase ${ }^{7}$ & Consumed & kcal & Total kcal & $\%$ \\
\hline Extraction & 1 & $555000 \mathrm{ha}^{-1}$ & 555000 & 7.77 \\
\hline Refining & 1 & $581000 \mathrm{ha}^{-1}$ & 581000 & 8.13 \\
\hline Transesterification & 1 & $1506000 \mathrm{ha}^{-1}$ & 1506000 & 21.07 \\
\hline Total & - & - & 2642000 & 36.97 \\
\hline Total Inputs & - & - & 7146537 & 100 \\
\hline \multicolumn{5}{|c|}{ - } \\
\hline Oil & $600 \mathrm{~kg}$ & 8900 & 5340000 & - \\
\hline Oil cake & $900 \mathrm{~kg}$ & 5100 & 4590000 & - \\
\hline Energy produced & - & - & 9930000 & - \\
\hline Energy Balance & - & - & 1.39 & - \\
\hline
\end{tabular}

${ }^{*}$ Values obtained according to the energy ratios of the following studies: ${ }^{1}$ SIQUEIRA et al., 1999, ${ }^{2}$ SOARES et al., 2007, ${ }^{3}$ MELLO, 1989, ${ }^{4}$ FREITAS et al., 2006, ${ }^{5}$ PIMENTEL \& PATZEK, 2005, ${ }^{6}$ GARAVAND et al., 2010, ${ }^{7}$ BATCHELOR et al., 1995. 
crops such as soybean, which is the main feedstock for biodiesel production in Brazil. UNAKITAN (2010) obtained an energy balance of 4.68 from a mean yield of $3,099.89 \mathrm{~kg} \mathrm{ha}^{-1}$ of canola grains, considering only the embedded energy value per $\mathrm{kg}$ of produced grains. For the soybean crop, GAZZONI et al. (2005) obtained an energy balance of 4.75 for a yield of $4,000 \mathrm{~kg} \mathrm{ha}^{-1}$, considering the yields in energy contained in the produced oil and oil cake.

Grain yields obtained by canola producers in Paraguay were greater than $2,044 \mathrm{~kg} \mathrm{ha}^{-1}$ and the genetic materials used have the potential to produce up to $4,500 \mathrm{~kg}$ of grains $\mathrm{ha}^{-1}$ (TOMM, 2006). The production of $1,500 \mathrm{~kg} \mathrm{ha}^{-1}$ that was obtained in the present study is generally considered medium-low. Increasing production would be a good alternative to increase the energy and the systems' yields.

Considering the technologies used, the greatest monetary costs of the agricultural phase (canola grain production) were related to the inputs, which represented $50.67 \%$ of the total production costs (Table 2). Mechanized operations and labor force represented approximately $36.45 \%$ and $12.88 \%$, respectively, of the total costs of production. The total monetary cost of the agricultural phase of the production of one hectare of canola was approximately $\mathrm{R} \$ 1,048.13$ (Table 2).

Conversely, the monetary yield for the crop, considering the grains produced and their commercial value in the regional market in 2012, was approximately $\mathrm{R} \$ 2,025.00$. The positive return in terms of economic balance of the agricultural phase of canola production indicated that this crop has economic potential for grain production in the region. However, because the cost analysis was based on the conditions required for the present study, further studies are needed to investigate the economic viability of canola grain production for a variety of purposes, including biodiesel production, in a wide range of production conditions.

The results indicated that the main production bottle necks were associated with the agricultural phase of production and that, in this phase, the inputs corresponded both with the highest energy expenditures and with the highest monetary costs. Therefore, investments should be made to improve the

Table 2 - Economic balance of the agricultural phase for the production of 1,500 kg/ha of canola grains in the region of Itumirim/Lavras, Minas Gerais, Brazil, 2012.

\begin{tabular}{|c|c|c|c|c|}
\hline & Quantity & Value/Unit & Total & Percentage \\
\hline Agricultural phase & Hour/machine & $\mathrm{R} \$$ & $\mathrm{R} \$$ & $\%$ \\
\hline \multicolumn{5}{|l|}{ Mechanization } \\
\hline Plowing & 1 & 50,00 & 50,00 & 4.77 \\
\hline Harrowing & 2 & 50,00 & 100,00 & 9.54 \\
\hline Sowing & 1 & 50,00 & 50,00 & 4.77 \\
\hline Insecticides & 0.6 & 50,00 & 30,00 & 2.86 \\
\hline Herbicides & 0.6 & 50,00 & 30,00 & 2.86 \\
\hline Fertilizers & 0.12 & 50,00 & 6,00 & 0.57 \\
\hline Harvest & 1 & 100,00 & 100,00 & 9.54 \\
\hline Transportation & 0.5 & 32,00 & 16,00 & 1.53 \\
\hline Total & - & - & 382,00 & 36.45 \\
\hline Labor force & Hour/man & & & \\
\hline Total & 36 & 3.75 & 135.00 & 12.88 \\
\hline Imputs & $200 \mathrm{~kg}$ & 1.19 & 238.00 & 22.71 \\
\hline $4-30-16$ & $100 \mathrm{~kg}$ & 0.71 & 71.00 & 6.77 \\
\hline Ammon Sulfate & $71 \mathrm{~kg}$ & 1.03 & 73.13 & 6.98 \\
\hline Urea & $2 \mathrm{~L} \mathrm{ha}^{-1}$ & 7.00 & 14.00 & 1.34 \\
\hline Glyphosate Methamidophos & $2.5 \mathrm{~L} \mathrm{ha}^{-1}$ & 14.00 & 35.00 & 3.34 \\
\hline Seeds & $4 \mathrm{~kg}$ & 1.50 & 6.00 & 0.57 \\
\hline Diesel & $47 \mathrm{~L}$ & 2.00 & 94.00 & 8.97 \\
\hline Total & - & - & 531.13 & 50.67 \\
\hline Total cost & & & 1048.13 & 100 \\
\hline Yields (kg grains) & 1500 & 1.35 & 2025 & - \\
\hline Economic balance & - & - & 1.93 & - \\
\hline
\end{tabular}

Ciência Rural, v.47, n.2, 2017. 
technologies used and to familiarize farmers in various regions of Brazil with the cultivation of canola. In addition, it is clear that there is a need for investment in genetic improvement programs to obtain cultivars that are more adapted to our plantation regions. These improvements would increase mean yields as well as the energy and economic potential of this crop in Brazil.

\section{CONCLUSION}

Results indicated the energy viability of biodiesel production from canola.

\section{ACKNOWLEDGEMENTS}

We thank the Fundação de Amparo á Pesquisa do Estado de Minas Gerais (FAPEMIG) for providing financial support, the Conselho Nacional de Desenvolvimento Científico e Tecnológico $(\mathrm{CNPq})$ for funding the project, the Universidade Federal de Lavras for providing the technology, and the Hortiagro Sementes S.A. for providing the infrastructure.

\section{REFERENCES}

BATCHELOR, S. E. et al. Energy analysis of rape methyl ester (RME) production from winter oilseed rape. Industrial Crops and Products, v.4, n.3, p.193-202, oct. 1995. Avaible from: <http:// www.sciencedirect.com/science/article/pii/0926669095000328>. Acessed: oct. 18, 2016. doi: 10.1016/0926-6690(95)00032-8.

CAMPOS, A.T.; CAMPOS, A.T.D. Balanços energéticos agropecuários: uma importante ferramenta como indicativo de sustentabilidade de agroecossistemas. Ciência Rural, v.34, n.6, p.1977-1985, dec. 2004. Available from: <http://dx.doi. org/10.1590/S0103-84782004000600050>. Acessed: oct. 18 , 2016. ISSN 1678-4596.

FREITAS, S.M.D. et al. Análise comparativa do balanço energético do milho em diferentes sistemas de produção. In: CONGRESSO DA SOBER, n.64, jul. 2006, Fortaleza, Ceará. Anais... Fortaleza: SOBER, 2006. 13 p. Available from: <http://www.sober.org.br/ palestra/5/963.pdf>. Acessed: oct. 18, 2016.

GARAVAND, A.T. et al. Energy elevation and economic analysis of canola production in Iran a case study: Mazandaran province. International Journal of Environmental Sciences, v.1, n.2, p.236-242, 2010. Available from: <http://citeseerx.ist.psu.edu/ viewdoc/summary; jsessionid=03944D045E6591083CF3C08C382 4FED4?doi=10.1.1.207.2099>. Acessed: oct. 18, 2016.

GARCEZ, C.A.G.; VIANNA, J.N.D.S. Brazilian biodiesel policy: social and environmental considerations of sustainability. Energy, v.34, n.5, p.645-654, may 2009. Available from: <http://dx.doi. org/10.1016/j.energy.2008.11.005>. Acessed: oct. 18, 2016.

GAZZONI, D.L. et al. Energy balance of soybean and sunflower for biodiesel production. Biomassa \& Energia, v.2, n.4, p.259-265, mar. 2005. Available from: <http://www.renabio.org.br/01-035-B\&E2005-p259-265.pmd.pdf>. Acessed: oct. 18, 2016.

KOHLHEPP, G. Análise da situação da produção de etanol e biodiesel no Brasil. Estudos Avançados, v.24, n. 68, p. 223-253, aug. 2010. Available from: <http://dx.doi.org/10.1590/S010340142010000100017>. Acessed: oct.18, 2016. ISSN 0103-4014.

MELLO, R.D. Um modelo para análise energética de agroecossistemas. Revista de Administração de Empresas, v.29, n.4, p.45-61, dec. 1989. Avaible from: <http://dx.doi.org/10.1590/S003475901989000400005>. Acessed: oct. 19, 2016. ISSN 0034-7590.

PIMENTEL, D.; PATZEK, T.W. Ethanol production using corn, switchgrass, and wood; biodiesel production using soybean and sunflower. Natural Resources Research, v.14, n.1, p.65-76, march. 2005. Available from: 〈http://journeytoforever.org/biofuel_library/Pimentel-Tadzek.pdf > Acessed: oct. 19, 2016. doi: 10.1007/s11053-005-4679-8.

SIQUEIRA, R. et al. Balanço de energia na implantação e manejo de plantas de cobertura do solo. Engenharia Agrícola, v.19, n.1, p.___, set. 1999

SOARES, L.H.D.B. et al. Balanço energético de um sistema integrado lavoura-pecuária no Cerrado. Seropédica: EMBRAPA Agrobiologia, 2007. 16 p. Available from: <http://www.bdpa. cnptia.embrapa.br/consulta/busca? $\mathrm{b}=\mathrm{ad} \& \mathrm{id}=622542 \&$ biblioteca $=$ vazio $\&$ busca $=622542 \& q$ Facets $=622542 \&$ sort $=\&$ paginacao $=t \& p a$ ginaAtual=1>. Acessed: oct. 2015.

SOUZA, R.D. Análise da conjuntura agropecuária safra 2008/09 - Biodiesel. Local: Departamento de economia rural. Estado do Paraná, Secretaria da Agricultura e Abastecimento. 2008. 10 p. Available from: <http://www.agricultura.pr.gov.br/arquivos/File/ deral/Prognosticos/biodiesel_0809.pdf>. Acessed: oct. 2016.

TOMM, G.O. Canola: alternativa de renda e benefícios para os cultivos seguintes. Revista Plantio Direto, v.15, n.94, p.48, jul. 2006. Available from: <http://www.plantiodireto.com. br/?body=cont_int\&id=727>. Acessed: oct. 19, 2016.

TOMM, G.O. et al. Panorama atual e indicações para aumento de eficiência da produção de canola no Brasil. Passo Fundo: Ministério da Agricultura, Pecuária e Abastecimento, dec. 2009. 34 p. Available from: <http://www.cnpt.embrapa.br/biblio/do/p_do118. pdf>. Acessed: oct. 19, 2016. ISSN 1518-6512.

UNAKITAN, G. et al. An analysis of energy use efficiency of canola production in Turkey. Energy, v.35, p.3623-3627, sep. 2010. Available from: <http://dx.doi.org/10.1016/j.energy.2010.05.005>. doi: 10.1016/j.energy.2010.05.005. 